\title{
Karol Popławski
}

\section{Cztery regulaminy porządkowe ustanowione przez podmioty prywatne - raport $\mathrm{z}$ badań $^{1}$}

\section{STRESZCZENIE}

Przenoszenie zadań zwyczajowo zarezerwowanych dla organów państwowych na podmioty prywatne jest faktem. Wiąże się to jednak z przekazaniem na rzecz tych podmiotów części kompetencji w kreowaniu praw i obowiązków jednostki. Najczęściej władczą formę wyrazu ich woli pełnią regulaminy. Charakteryzują się one różną forma, treścia, a nawet funkcją. Jednocześnie jednak regulaminy, zależąc wyłącznie od woli podmiotów prywatnych, niejednokrotnie zbyt dalece ingerują w sferę wolności i praw ich odbiorców. Tym samym badania dotyczące ich istoty i przede wszystkim treści, w kontekście postępującego i skomplikowanego procesu „prywatyzacji bezpieczeństwa", wydają się tym istotniejsze. Stąd w opracowaniu podjęto się próby analizy opatrzonej krótkim komentarzem wobec postanowień regulaminów pływalni publicznych, imprezy masowej, obiektu (terenu) sportowego, a także klubu nocnego.

Słowa kluczowe: analiza regulaminów, praca badawcza, raport z badań

1 Analiza wykonana w ramach projektu badawczego „Prywatna ochrona bezpieczeństwa i jej normy”, „Niepaństwowe prawo" NCN OPUS - 5 Dec - 2013/09/B/ HS5/02671, której przedmiotem były regulaminy: obiektu sportowego należącego do klubu Wisła Kraków S.A. oraz regulamin imprezy masowej - meczu piłki nożnej odbywającego się na stadionie Wisły Kraków S.A., krytej pływalni Kozienice, Aquaparku Radom, klubu nocnego DeLitte. 


\title{
Karol Popławski
}

\section{Four by-laws laid down by private entities - students research report}

\begin{abstract}
Transfering duties customarly designated for public entities to private entities is a fact. It is connected with delegating on them a part of legal power in creating rights and duties of individuals. A vast majority of their domineeringly will is commonly stated on the grounds of by-laws. By-laws have different form, content and even different function. At the same time, depending only on the will of private entities several times interfere in the freedom and the rights of their addressee. That is why scientifical research concerning their essence and content, including a progressive and complicated process of "privatisation of public safety" seem to be more and more important. On the ground of this research, several by-laws laid down by private entities are being analysed.
\end{abstract}

Keywords: by-laws analysis, research, research report 
Stale zwiększająca się liczba zadań zlecanych lub delegowanych poszczególnym podmiotom, np. samorządowym lub organizacjom pozarządowym, względnie korporacjom gospodarczym jest faktem, co sprzyja jednocześnie rozproszeniu różnych form kontroli i odpowiedzialności pomiędzy poszczególne podmioty. W rezultacie sprzyja to również powstaniu coraz większych przestrzeni w zakresie regulacji prawnych. Są one jednak coraz skuteczniej wypełniane przez różnorakie normy pozaprawne ${ }^{2}$. Do takich zaliczyć należy chociażby regulaminy.

W ramach projektu badawczego należało dokonać analizy poszczególnych regulaminów, poszukując jednocześnie odpowiedzi na pytanie, w jakim zakresie podmioty państwowe pozbywają się zakresu swojej odpowiedzialności $\mathrm{w}$ różnych - niekiedy bardzo newralgicznych - obszarach prawa, obarczając nimi podmioty prywatne? W efekcie wiąże się to z uzyskaniem przez nie określonej części kompetencji w zakresie kreowania praw i obowiązków. Władczą formą wyrażenia ich woli staje się wówczas właśnie regulamin. Stąd bardzo ważne wydaje się poddanie analizie treści poszczególnych regulaminów. Miało to przynieść odpowiedź na pytanie - jaką w istocie władzą cieszą się podmioty prywatne i w rezultacie, czy podlega ona jakiejkolwiek limitacji?

Regulaminy charakteryzują się ogromną różnorodnością formy, treści, a nawet funkcji pełnionych we współczesnych policentrycznych systemach prawnych. Swoboda formy to przede wszystkim dowolność w kształtowaniu ich postanowień przez poszczególne podmioty - głównie prywatne - odpowiedzialne za ich wydanie. Najczęściej zaliczać będą się do nich organizatorzy (tak jak w przypadku regulaminu klubu nocnego lub regulaminów imprez masowych). Nie oznacza to jednak, iż wzmiankowane podmioty przez sam fakt wydania regulaminu uzyskują kompetencję do kształtowania sytuacji prawnej adresatów tego regulaminu. Swoistą i nieprzekraczalną granicą są bowiem limity ingerencji w sferę praw i obowiązków jednostki wyznaczone przez ustawy, co najdobitniej widać na przykładzie bardzo ścisłej relacji pomiędzy regulaminami obiektów piłkarskich oraz regulaminami imprez masowych w tych obiektach realizowanych a samą ustawą o bezpieczeństwie imprez masowych ${ }^{3}$.

2 J. Jabłońska-Bonca, Policentryczność źródeł norm w zakresie bezpieczeństwa obywateli. Problem czy margines?, „Krytyka Prawa” 2015, nr 1, s. 1.

3 Ustawa z dnia 20 marca 2009 r. o bezpieczeństwie imprez masowych (Dz.U. z 2009 r. Nr 62, poz. 504). 
Jednocześnie, zależnie od obszaru objętego regulacją regulaminową różnić będzie się także zakres adresatów i sposób ogłoszenia regulaminu. Można nawet zaryzykować twierdzenie, iż regulaminy często nie są oficjalnie publikowane, nie będąc też powszechnie dostępnymi, co może powodować stan swoistej „,konfuzji” po stronie obywateli, którzy na ogół nie mają świadomości: kto i w jakim zakresie ma nad nimi władzę. Tym bardziej, że organy państwowe, tradycyjnie sprawujące władzę w określonych obszarach, takich jak chociażby bezpieczeństwo, niejednokrotnie nie nadzorują w odpowiednim zakresie procesu powstawania i treści samych regulaminów. Prowadzi to niekiedy do łamania fundamentalnych zasad demokratycznego państwa prawnego, co wywiódł Trybunał Konstytucyjny w wyroku o sygn. K 17/134 . Tym istotniejsza wydaje się analiza treści regulaminów, ponieważ, jak wskazał Trybunał, proces prywatyzacji poszczególnych zadań państwowych, takich jak chociażby ochrona bezpieczeństwa, jest zadaniem wymagającym, które, będąc pozostawione bez kontroli, może prowadzić niekiedy do naruszenia praw jednostki.

Abstrahując od kwalifikacji (w tym prawnej) regulaminów, która jest różna, przyjąć należy, iż pomimo względnej swobody w kształtowaniu treści regulaminów, wymagana jest ich zgodność z obowiązującym prawem. Nie dotyczy to jednak wszystkich założeń regulaminów. Podmiot, względnie organ odpowiedzialny za ich wydanie, zawsze będzie cieszył się pewną swobodą w kształtowaniu regulaminowych postanowień. Oczywiście nie ma zgody na implementowanie na gruncie regulaminów postanowień niezgodnych z prawem. Regulaminy są jednak egzemplifikacją płynnej granicy pomiędzy normami o charakterze generalnie abstrakcyjnym a normami konkretnie indywidualnymi.

\footnotetext{
4 Wyrok z dnia 20 maja 2014 r., K 17/13 (53/5/A/2014). Przedmiotem badania była zgodność ustawy o bezpieczeństwie imprez masowych (Dz.U. z 2009 r. Nr 62, poz. 504 ze zm.) z powszechnie obowiązującym prawem w zakresie art. 54 ust. 1, w części odnoszącej się do słów „regulamin obiektu (terenu) lub regulamin imprezy masowej". W efekcie stwierdzono niezgodność artykułu z art. 42 ust. 1 Konstytucji RP. Przepis ten w dotychczasowym brzmieniu wymagał mianowicie dopatrywania się znamion czynu zabronionego w regulaminach, które nie są powszechnie obowiązującymi aktami prawnymi w myśl art. 87 Konstytucji RP.
} 


\section{REGULAMINY OBIEKTU SPORTOWEGO ORAZREGULAMINYIMPREZYMASOWEJWKONTEKŚCIE WYROKU TRYBUNAŁU KONSTYTUCYJNEGO K 17/13 ORAZUSTAWYOBEZPIECZEŃSTWIEIMPREZMASOWYCH}

Na wstępie podkreślić należy bardzo silną zależność pomiędzy regulaminem obiektu sportowego a regulaminem imprezy masowej i ustawy o bezpieczeństwie imprez masowych. Sama ustawa zawiera przepisy z zakresu prawa administracyjnego, karnego oraz cywilnego i powstała w celu zapewnienia podmiotom bezpiecznego uczestnictwa w imprezach masowych ${ }^{5}$. Jej powstanie wywołane było postępującym zjawiskiem bandytyzmu stadionowego, wobec którego dotychczasowe regulacje pozostawały niedostatecznie skuteczne. Interesującym rozwiązaniem wprowadzonym przez nowe ustawodawstwo była kwestia zakazu klubowego. Jest to o tyle interesujące, iż założenia te implikowane są na gruncie regulaminów imprez masowych. Impreza masowa natomiast, to według art. 3 pkt 1 ustawy o bezpieczeństwie imprez masowych: „impreza masowa artystyczno-rozrywkowa, masowa impreza sportowa, w tym mecz piłki nożnej". Jej organizacja może jednak, ale nie musi - według opinii doktryny - być zorientowana na osiągnięcie zysku. Istnieje także katalog imprez niemieszczących się w zakresie powyższej definicji, co ma istotny wymiar praktyczny. Ex definitione katalog imprez mieszczących się w zakresie imprez masowych będzie ściśle określony. Wszystko, co nie będzie mieścić się w definicji imprezy sportowej lub artystyczno-rozrywkowej ex lege nie może być zakwalifikowane jako impreza masowa. W efekcie za takie nie uznamy zatem pielgrzymek lub wesel, ale dyskoteki lub nawet juwenalia studenckie już tak ${ }^{6}$.

W art. 3 pkt 10 ustawy o bezpieczeństwie imprez masowych znajduje się jednoznaczna definicja legalna regulaminu obiektu (terenu). Przez regulamin należy rozumieć „przepisy wydane przez właściciela, posiadacza, użytkownika lub zarządzającego obiektem lub terenem, zawierające zasady wstępu na teren lub obiekt, w tym osób małoletnich, zasady zachowania się osób obecnych $\mathrm{w}$ obiekcie lub na terenie i korzystania przez nie z obiektu

5 M. Dróżdż, Definicja imprezy masowej- teoria a praktyka „Edukacja Prawnicza” 2013, nr 10, s. 3-6.

6 Ibidem. 
lub terenu oraz znajdujących się tam urządzeń, a także określające miejsca nieprzeznaczone dla publiczności". Tymczasem na podstawie art. 6 ust. 3 ustawy o bezpieczeństwie imprez masowych, regulamin imprezy masowej powinien zawierać „,warunki uczestnictwa i zasady zachowania się osób na niej obecnych". W tym kontekście warto również przywołać definicję organizatora, który w większości przypadków jest podmiotem odpowiedzialnym za wydanie regulaminu. Zgodnie z definicją zawartą w art. 3 pkt 9 ustawy o bezpieczeństwie imprez masowych organizator to: „osoba prawna, osoba fizyczna lub jednostka organizacyjna nieposiadająca osobowości prawnej, przeprowadzająca imprezę masową". Zgodnie z art. 5 ust. 1 tej samej ustawy ponosi on odpowiedzialność za bezpieczeństwo imprezy masowej, a także ipso facto udostępnia odpowiedni regulamin uczestnikom imprezy masowej. W wyroku K 17/13 Trybunał Konstytucyjny podtrzymał opinię wnioskodawcy - Rzecznika Praw Obywatelskich - o tym, że organizator powinien być jednak postrzegany głównie jako podmiot prywatny. Wnioskodawca „podniósł także zarzut niezgodności art. 54 ust. 1 ustawy o bezpieczeństwie imprez masowych $\mathrm{z}$ art. 87 ust. 1 Konstytucji, który ustanawia zamknięty katalog źródeł prawa, nie przewidując w nim regulaminów wydawanych przez podmioty prywatne" ${ }^{7}$.

Zgodnie z tak przyjętym rozumowaniem regulaminy mogą być źródłem nie tyle prawa, ile poleceń porządkowych. Przez takie, według Trybunału Konstytucyjnego, należy rozumieć określony nakaz zachowania przybierający najczęściej - w realiach stadionowych - formę komunikatu werbalnego wydawanego przez spikera, który sprowadza się w ogólności do informowania uczestników o przyjętych rozwiązaniach organizacyjnych (art. 3 pkt 12 i 13 w związku z art. 19 ust. 1 i $2^{8}$ ). Jak zważył Trybunał: „niezależnie od formy wydania polecenia powinno ono mieć charakter stricte porządkowy, czyli taki, który ma zmierzać wyłącznie i bezpośrednio do przywrócenia stanu sprzed naruszenia porządku publicznego czy określonego

7 Zostało to jednak zakwestionowane przez Marszałka Sejmu, który „,wskazał, że obowiązek przestrzegania regulaminów obiektu (terenu) oraz imprezy masowej nie wynika z samych regulaminów, lecz z ustawy, która odsyła do tych aktów jako konkretyzujących jej postanowienia w odniesieniu do realiów konkretnej imprezy masowej. Źródłem wspomnianego obowiązku pozostaje więc ustawa o bezpieczeństwie imprez masowych, a w szczególności art. 8 ust. 1 ustawy o bezpieczeństwie imprez masowych". Podkreśliłjednocześnie, iż regulaminy stadionowe (regulamin terenu i regulamin imprezy masowej) są jednak aktami zakładającymi obligatoryjność ich przestrzegania jako aktów implementujących przepisy ustawy. 8 TK w wyroku K 17/13 za B. Kurzępa, Przestępstwa i wykroczenia z ustawy o bezpieczeństwie imprez masowych, „Prokuratora i Prawo” 2009, nr 10, s. 65. 
postanowienia regulaminu. Nie może ono zmierzać do dokuczenia uczestnikowi, poniżenia go czy ośmieszenia w oczach innych uczestników" ${ }^{\prime 9}$. Jak Trybunał Konstytucyjny podkreślił, później istnieje jednak realne ryzyko rozszerzenia zakresu miejsc, w których moc obowiązującą będą miały polecenia (np. parking, chodnik wokół stadionu, jednak tylko o tyle, o ile służby porządkowe wypełniają tam swoje obowiązki związane z zapewnieniem bezpieczeństwa) ${ }^{10}$. Podnosi się jednak, że „samo zachowanie niezgodne z Ustawą o bezpieczeństwie imprez masowych czy postanowieniami regulaminów nie stanowi - samo w sobie - niewykonania polecenia porządkowego, ponieważ normy wynikające $\mathrm{z}$ tych przepisów nie stanowią tych poleceń porządkowych"11. Wyraźnie zatem regulaminy stanowią przejaw władztwa.

Należy zgodzić się z twierdzeniem Trybunału, iż „postanowienia regulaminów mają istotne znaczenie z punktu widzenia organizacji i przebiegu imprezy, a także funkcjonowania obiektu (w czasie i poza imprezą), to jednak nie wszystkie z nich odnoszą się stricte do zapewnienia bezpieczeństwa imprezy masowej. Wszystkie natomiast mogą być podstawą wydawania poleceń przez służby porządkowe i informacyjne”. W efekcie „regulaminy obiektu (terenu) i regulaminy imprezy masowej mogą obejmować bardzo różne zakazy i nakazy, które niekiedy bardzo głęboko ingerują w sferę wolności, swobody poruszania się czy w prywatność uczestników imprez masowych. Podmiotom zobowiązanym do opracowania regulaminów pozostawiono znaczną swobodę do określania przedmiotu czynności wykonawczej". Trybunał zważył, iż tak szeroka, dopuszczalna regulacja nakazów i zakazów uchybia proporcjonalności stosowanych środków wobec różnego zachowania uczestników. Godzi to zatem w jego opinii w podstawowe zasady prawa karnego, a nawet Konstytucji. Zgodnie bowiem $\mathrm{z}$ aktualnie obowiązującym stanem regulacji regulaminowych, uczestnicy podlegać będą tej samej odpowiedzialności za niewykonanie lub nienależyte wykonanie poleceń właściwych służb organizatora, bez względu na stopień zawinienia. W rezultacie przymusowemu wydaleniu z obiektu i ewentualnie dalszej odpowiedzialności prawnokarnej podlegać będą osoby posiadające broń, nóż lub wnoszące na jego teren środki pirotechniczne, jak

9 TK w wyroku K 17/13 za C. Kąkol, Komentarz do art. 54 Ustawy o bezpieczeństwie imprez masowych, LEX 2012.

10 TK w wyroku K 17/13 za B. Kurzępa, op. cit., s. 65.

11 C. Kąkol, op. cit. 
również te osoby, które zanieczyszczają lub zaśmiecają teren (obiekt) lub wykorzystują urządzenia niezgodnie $\mathrm{z}$ ich przeznaczeniem, naturalnie wbrew woli organizatora (co zostanie wykazane przy bezpośredniej analizie treści regulaminów). Stoi to w oczywistej sprzeczności z dyrektywami kary, która winna być przecież adekwatna do stopnia winy, godząc jednocześnie w fundamentalną zasadę demokratycznego państwa prawnego ${ }^{12}$. To z kolei prowadzi do konkluzji, iż dotychczasowa regulacja pozwalała na ograniczenie dóbr wyższej wartości (wolność, nietykalność osobista), kosztem ochrony dóbr określonych $\mathrm{w}$ regulaminach - dla przykładu rozprowadzanie materiałów reklamowych bez zezwolenia.

\section{ANALIZATREŚCIREGULAMINUOBIEKTUSPORTOWEGO PRZYUL.REYMONTA22WKRAKOWIEORAZREGULAMINU IMPREZY MASOWEJ - MECZU PIŁKI NOŻNEJ ORGA NIZOWANEJ NA STADIONIE WISEY KRAKÓW S.A.}

1.

Regulamin obiektu sportowego przy ul. Reymonta 22 w Krakowie ${ }^{13}$ zaczyna się od wymienienia podstawy prawnej: „na podstawie art. 6 ust. 3 ustawy z dnia 20 marca 2009 r. o bezpieczeństwie imprez masowych (Dz. U. Nr 62, poz. 504) oraz zmianach (Dz. U. z 2010 r. nr 152 poz. 1021, Dz. U. z 2010 r.

\footnotetext{
12 Sędziowie Trybunału Konstytucyjnego zważyli, iż zakwestionowany i w efekcie niezgodny z Konstytucją art. 54 ust. 1 ustawy o bezpieczeństwie imprez masowych dopuszczał regulowanie odpowiedzialności karnej uczestników przez ustalenie wysokości kary grzywny na gruncie regulaminów obiektu (terenu) oraz regulaminów imprezy masowej właściwych klubów piłki nożnej w Polsce. Sędziowie zwrócili uwagę na to, iż zgodnie z przepisami Kodeksu wykroczeń karę grzywny można zmienić np. na karę ograniczenia wolności. Tym samym podmioty prywatne uzyskiwały $w$ ten sposób potencję $w$ zakresie kreowania odpowiedzialności karnej. Trybunał uznał również, że „możliwy zakres odesłania regulacyjnych norm blankietowych musi czynić zadość wyznaczonym przez Konstytucję granicom kompetencji prawotwórczych organów władzy publicznej". Tym silniej podkreślono, że ustawodawca określił relację łączącą organizatora i uczestnika imprezy masowej jako opartą na zasadach prawa cywilnego. Z tego wynika jasno, iż odpowiedzialność finansowa za określone działania uczestnika imprezy masowej nie powinna być interpretowana jako kara grzywny, a jako potencjalnie wynikająca z kary umownej. W opinii Trybunału, stosunki te podporządkowano koncepcji tzw. umów adhezyjnych.

${ }^{13}$ Regulamin obiektu (terenu), jak również regulamin imprezy masowej dostępne pod adresem: http:// bp.wisla.krakow.pl/files/Regulamin_stadionu.pdf.
} 
nr 127 poz. 857, Dz. U. z 2011 r. nr 217 poz. 1280) wprowadza się niniejszy regulamin imprezy masowej" ${ }^{14}$. Jednostką redakcyjną regulaminu jest paragraf. Ponadto $\S 3$ zawiera wyraźne odesłanie do regulaminu imprezy masowej, określającego „szczegółowe zasady postępowania i dostępności obiektu dla publiczności w czasie trwania imprezy masowej". Kolejne paragrafy (tj. $\S 4$ i $\S 5$ ) pełnią m.in. funkcję informacyjną przez podanie, iż obiekt wyposażony jest w elektroniczny system identyfikacji osób służący do sprzedaży biletów, kontroli zachowania osób obecnych na obiekcie oraz kontroli dostępu do określonych miejsc na obiekcie, jak również nadmienia, iż obiekt podlega monitorowaniu.

Niewątpliwie godny odnotowania jest $\S 6$, który wymienia czynności polegające na sprawdzaniu rzeczy, bagażu itp. (§ 6 ust. 2) oraz obowiązkowym stosowaniu się przez użytkowników do poleceń porządkowych wydawanych na podstawie regulaminu (§ 6 ust. 1). Tą właściwość regulaminu bardzo silnie zaakcentował TK we wspominanym już wyroku K 17/13. $\S 6$ ust. 1 bardzo szeroko określa zakres podmiotów zdolnych do wydawania poleceń porządkowych, zaliczając do nich „organizatora imprezy/ właściciela/zarządcę/użytkownika obiektu, a w przypadku interwencji funkcjonariuszy Policji, Państwowej Straży Pożarnej, Straży Granicznej, Żandarmerii Wojskowej lub pracowników innych uprawnionych służb i organów". Co interesujące, regulamin nie wspomina o poleceniach wydawanych przez spikera, co wyraźnie podkreślił Trybunał. Jednak należy sądzić, iż mieści się on w powyższym zakresie desygnatów. Jednocześnie zgodnie z brzmieniem $\S 6$ ust. 2 organizator przyją „prawo do odmowy wstępu lub usunięcia z obiektu każdej osoby odmawiającej poddania się tym czynnościom".

Na uwagę zasługuje użyte powyżej określenie pracowników innych uprawnionych służb i organów. Przez takich należy rozumieć członków służb porządkowych, a zatem upoważnione przez organizatora osoby, które ukończyły szkolenie przewidziane w przepisach wydanych na podstawie art. 23 ustawy o bezpieczeństwie imprez masowych. Zgodnie z wykładnią Trybunału Konstytucyjnego działają one na rzecz bezpieczeństwa i porządku publicznego w czasie i miejscu trwania imprezy masowej ${ }^{15}$.

\footnotetext{
14 Taka redakcja jest najprawdopodobniej wynikiem błędu organizatora, ponieważ oczywiste jest, iż mowa o regulaminie obiektu (terenu). Jest to zresztą wprowadzenie o identycznej treści, jak w przypadku regulaminu imprezy masowej organizowanej na stadionie Wisły Kraków S.A.

15 Uzasadnienie do wyroku z dnia 20 maja 2014 r., K 17/13, s. 13.
} 
Następnie organizator określił w regulaminie szczegółowe zasady dostępności obiektu, zapewniające ciągłość jego funkcjonowania w dniach, w których imprezy masowe nie są organizowane (§9), reglamentując jednocześnie jakąkolwiek działalność handlowa, gastronomiczną, usługowa, artystyczna, a przede wszystkim związaną z filmowaniem lub wykonywaniem zdjęć - z zastrzeżeniem czynności służbowych prowadzonych przez Policję - odbywających się wbrew woli organizatora, właściciela, zarządcy lub użytkownika (§ 10 ust. 1 i 2). Ponadto dzieci poniżej 13. roku życia, zgodnie z brzmieniem $\S 7$, mogą wstępować i przebywać na obiekcie jedynie pod opieką dorosłych.

W § 12 zawarta jest natomiast kluczowa z punktu widzenia istoty regulaminu kwestia. Ustala on bowiem katalog rzeczy, których wnoszenie i posiadanie jest na terenie obiektu zakazane. Zgodnie z jego treścią zabrania się wnoszenia i posiadania na terenie obiektu w szczególności: „broni, amunicji oraz innych niebezpiecznych przedmiotów, mogących stanowić zagrożenie dla życia i zdrowia ludzi lub mienia; materiałów wybuchowych, wyrobów pirotechnicznych oraz substancji o podobnym działaniu oraz wszelkiego rodzaju materiałów pożarowo niebezpiecznych". Ponadto reglamentacji podlegają pojemniki na płyny lub produkty spożywcze wykonane $\mathrm{z}$ twardego materiału, $\mathrm{w}$ tym butelki plastikowe, a w tym, w szczególności, alkohol, środki odurzające i psychotropowe lub inne podobnie działające środki. Źródłem wielu dyskusji jest pkt 5 § 12, który stanowi o absolutnym zakazie wnoszenia na obiekt kasków oraz parasoli o ostrym zakończeniu. Zwłaszcza ostatni wymóg rodził kontrowersje i postrzegano go jako absurdalny. Spośród przedmiotów potencjalnie niebezpiecznych organizator wyodrębnił również pojemniki do rozpylania gazu, substancji żrących lub farbujących ( $§ 12 \mathrm{pkt} 7)$. Ponad to penalizowane jest posiadanie na obiekcie przedmiotów, które z uwagi na swe kształty lub/i rozmiary nie mogą być schowane pod siedzenie ( 112 pkt 8 ), a nawet wskaźników laserowych (§12 pkt 10). Ten ostatni zakaz należy utożsamiać jednak głównie z komfortem zawodników, ponieważ dzięki niemu uniemożliwia się oślepianie piłkarzy.

Istotną część $\S 12$ stanowią także przedmioty związane bezpośrednio z kibicowaniem. Są to, według organizatora, przede wszystkim materiały zawierające treści rasistowskie, polityczne, ksenofobiczne lub wulgarne oraz tak zwane wlepki (§ 12 pkt 6), jak również trąbki, wuwuzele oraz instrumenty z napędem mechanicznym lub elektrycznym ( 112 pkt 9). Postanowienia te przyjęto różnie, w zależności od środowiska społecznego, z którego 
określeni kibice się wywodzili. W debacie publicznej pojawiły się opinie, jakoby przesadnie dbano na stadionach o poprawność polityczną, krępując swobodę zachowania się kibiców. Podniesiono również, iż kupno biletów i uczestnictwo w imprezie masowej, zgodnie z ogólną wymową regulaminów, stawia kibiców niejako w roli przestępców ${ }^{16}$. Następnie $\S 12$ odnosi się do zakazu posiadania: „materiałów reklamowych, za wyjątkiem dopuszczonych za pisemną zgodą organizatora imprezy/właściciela/zarządcy/ użytkownika obiektu (§12 pkt 11); kamer i aparatów fotograficznych oraz innych tego typu urządzeń rejestrujących dźwięk lub obraz, za wyjątkiem przeznaczonych do ściśle prywatnego użytku (§12 pkt 12); urządzeń służących do przesyłania obrazu, dźwięku, opisów wydarzeń poprzez Internet lub dokonywania innych form przekazu, za wyjątkiem dopuszczonych za pisemną zgodą organizatora (§ 12 pkt 13). W obiekcie (terenie), w którym odbywa się impreza masowa nie wolno także na podstawie pkt 14 powyższego par. wprowadzać zwierząt innych niż psy przewodniki".

W ścisłym związku praktycznym i logicznym z $\S 12$ pozostaje $\S 13$, który określa katalog różnych form zachowania zakazanych przez organizatora. Zgodnie z jego treścią zabrania się: przebywania na terenie obiektu osobie znajdującej się pod widocznym wpływem alkoholu, środków odurzających i psychotropowych lub innych podobnie działających środków, jak również przebywania w miejscach nieprzeznaczonych dla publiczności (§ 13 pkt 1 i 2). Przy czym zakaz powyższy dotyczy w szczególności: terenu, na którym rozgrywane są zawody sportowe, budowli i urządzeń nieprzeznaczonych dla powszechnego użytku, fasady obiektu, płotów, murów, ogrodzeń, dachów stadionu, urządzeń oświetleniowych, pomostów kamerowych, drzew, wszelkiego rodzaju masztów oraz wejścia do innych miejsc, urządzeń i pomieszczeń, do których dostęp mają wyłącznie służby specjalistyczne lub przedstawiciele organizatora imprezy. Zakazane jest także, zgodnie z wolą organizatora: rzucanie przedmiotami mogącymi stanowić zagrożenie dla życia i zdrowia osób znajdujących się na terenie obiektu; głoszenia i wywieszania haseł o treściach obscenicznych, wulgarnych i rasistowskich; nawoływania do waśni na tle narodowościowym, religijnym, społecznym itp. (§13 pkt 3 i 4). Niedozwolone jest także - zgodnie z brzmieniem pkt 5 - używanie elementów odzieży lub innych przedmiotów do

16 Szerzej na ten temat: www. polityka.pl/tygodnikpolityka/społeczeństwo/1582555,1,trybunal-kwestionuje-samowolke-w-regulaminach-stadionowych-kibice-się-ciesza.read. 
zakrycia twarzy w celu uniemożliwienia lub utrudnienia identyfikacji. Przepisy powyższe stanowią jedynie odzwierciedlenie idealnego, z punktu widzenia organizatora, stanu.

Praktyka stadionowa dalece jednak odbiega od przedstawionych powyżej wymogów. Na polskich stadionach konsekwentnie ignorowane są nakazy zachowania wyglądu umożliwiającego identyfikację. Trybuny najbardziej zagorzałych fanów pełne są także haseł i treści łamiących wytyczne punktów 3 i 4 § 13. Praktyka wizyt na stadionie podpowiada jednak, iż na tych dosyć szczególnych trybunach panuje bardzo interesujący sposób utrzymania dyscypliny. Można również przyjąć, że treść regulaminów jest doskonale znana każdemu z kibiców „prowadzących doping”, którzy po prostu odnoszą się do nich wybiórczo. Podczas jednej z wizyt na stadionie prowadzący doping bardzo silnie akcentował zakaz przebywania w miejscach do tego nieprzewidzianych, zgodnie zresztą z brzmieniem $\S 13$ pkt 3 . Niemniej jednak powszechnie używano wulgaryzmów oraz haseł, które mogły być uznane za nawołujące do nienawiści na różnym tle.

Ponadto zabrania się w obiekcie (terenie) imprezy masowej zanieczyszczania lub zaśmiecania obiektu, rozniecania ognia, używania urządzeń obiektu w sposób niezgodny z ich przeznaczeniem (§13 pkt 6, 7 i 8). Tymczasem $\S 13$ pkt 10 zakazuje umieszczania transparentów, flag lub elementów opraw w sposób ograniczający widoczność innym uczestnikom imprezy lub w sposób ograniczający widoczność materiałów reklamowych lub blokujący wyjścia i bramy ewakuacyjne. Taka regulacja jednak w bardzo ciekawym świetle stawia kwestię tzw. sektorówek, które niewątpliwie ubarwiają polskie stadiony. Niemniej jednak ich instalacja de facto ogranicza widoczność innym uczestnikom imprezy, oczywiście przez określony czas.

Na podstawie $\S 12$ i 13 regulaminu obiektu (terenu) sportowego przy ul. Reymonta 22 uznać trzeba, iż organizator określił katalog przedmiotów i zachowań zakazanych w sposób bardzo konkretny. Nie zabrakło jednak $\mathrm{w}$ treści powyższych norm regulacji będących podstawą do dyskusji, np. zakaz wnoszenia na stadion parasoli. Pośrednio odniósł się do tego Trybunał Konstytucyjny w wyroku K 17/13, pochylając się nad treścią art. 8 ust. 2 ustawy o bezpieczeństwie imprez masowych. Określa on katalog przedmiotów, których wnoszenie lub posiadanie na obiekcie (terenie) objętym władztwem regulaminowym jest zakazane, pozostawiając ten katalog otwartym przez stwierdzenie: „inne niebezpieczne przedmioty”. Najczęściej mowa jest jednak o przedmiotach powszechnie uznanych za niebezpieczne i w efekcie uregulowanych na gruncie poszczególnych innych 
ustaw. Dotyczyć będzie to broni i amunicji ${ }^{17}$ lub chociażby materiałów wybuchowych ${ }^{18}$. Zgodnie z wykładnią Trybunału Konstytucyjnego wszelkie polecenia porządkowe wydane np. na podstawie art. 22 ustawy o bezpieczeństwie imprez masowych w odniesieniu do powyższych przedmiotów, tj. broni, materiałów wybuchowych, toksycznych środków, należy uznać za takie, $\mathrm{u}$ podstaw których stoi ustawa. Tym samym a priori polecenia te należy uznać za całkowicie słuszne w majestacie prawa. Jednak wszelkie zakazy wniesienia i posiadania przedmiotów, o których nie wspominają konkretne ustawy, należy - w opinii Trybunału Konstytucyjnego - uznać za wydane bez podstawy prawnej. Bez względu na okoliczności złamanie któregokolwiek z postanowień § 12 bądź 13 może skutkować „usunięciem z obiektu". Tak przynajmniej reguluje to $\S 14$ regulaminu. Nie może jednak umknąć powszechnej uwadze także treść § 13. Określenie rodzaju zabronionego zachowania nie jest tam bowiem zróżnicowane pod kątem stopnia winy. W efekcie, tej samej odpowiedzialności dyscyplinarnej lub kontraktowej podlegać będzie użytkownik wnoszący na obiekt broń, jak również ten, który bez zgody organizatora roznosił ulotki. Godzi to w jasny sposób $\mathrm{w}$ koncepcję proporcjonalności, co było zresztą przywoływane na gruncie niniejszego opracowania.

Ponownie przywołać należy, iż Trybunał Konstytucyjny zwrócił uwagę na zbytnią ingerencję postanowień regulaminowych $\mathrm{w}$ sferę praw i obowiązków jednostki. Według stanowiska Rzecznika Praw Obywatelskich, będącego wnioskodawcą $\mathrm{w}$ przedmiotowej sprawie, potwierdzonego przez $\mathrm{TK}$, takim działaniem jest $\mathrm{w}$ istocie powszechnie występujący przepis dotyczący właściwego - w opinii organizatora - zajmowania miejsc przez użytkowników. W większości przypadków przepisy regulaminów obiektu (terenu) stanowia, że: „Uczestnik imprezy jest obowiązany zajmować miejsce określone $\mathrm{w}$ dokumencie uprawniającym do wejścia na imprezę masową", podczas gdy ustawa o bezpieczeństwie imprez masowych penalizuje „przebywanie w czasie trwania masowej imprezy sportowej w sektorze innym niż wskazany na bilecie wstępu lub innym dokumencie uprawniającym do przebywania na imprezie masowej i nieopuszczanie tego sektora mimo wezwania osoby uprawnionej (art. 54 ust. 2 pkt 2 ustawy)". Taka regulacja znalazła się w regulaminie obiektu (terenu) sportowego klubu Wisła

\footnotetext{
17 Na podstawie ustawy z dnia 21 maja 1999 r. o broni i amunicji (Dz.U. z 2014 r., poz. 576 ze zm.).

${ }^{18}$ Na podstawie ustawy z dnia 21 czerwca 2002 r. o materiałach wybuchowych przeznaczonych do użytku cywilnego (Dz.U. z 2012 r., poz. 1329 ze zm.).
} 
Kraków S.A., Legii Warszawa S.A., WKS Zawiszy Bydgoszcz S.A., co jednoznacznie wskazuje na powszechność regulacji tego typu. Trybunał Konstytucyjny nie zakwestionował jednak kompetencji organizatora do wymuszenia zmiany miejsc, o ile jest to podyktowane względami bezpieczeństwa.

$\S 14$ pkt 2 implementuje na gruncie regulaminu nowość wprowadzoną do ustawy o bezpieczeństwie imprez masowych w nowelizacji z 20 marca 2009 r., a mianowicie zakaz klubowy ${ }^{19}$. Polega on na ustanowieniu zakazu uczestnictwa w imprezach masowych wobec osób niestosujących się do zasad § 12 i § 13, w drodze arbitralnej decyzji organizatora. Jest ona wiążąca dla stron, którym przysługuje odwołanie do właściwego podmiotu zarządzającego rozgrywkami. W kolejnych normach zastrzeżono natomiast ewentualną zmianę jego postanowień, uzależnioną od uprzedniego ogłoszenia regulaminów ( $\$ 15$ ust. 2 Regulaminu) oraz wyrażono prawo do dochodzenia odszkodowania za wyrządzone szkody, w tym także „naruszenie dobrego wizerunku”. Na uwagę zasługuje fakt, iż organizator przywołał w $\S 15$ ust. 1 odpowiedzialność użytkowników ex contractu, podporządkowując relację na linii organizator-uczestnik imprezy masowej koncepcji umów adhezyjnych. Regulamin obiektu sportowego przy ul. Reymonta 22 wszedł w życie zgodnie z brzmieniem § 18 - 12 lutego 2012 r.

2.

Regulamin imprezy masowej organizowanej na stadionie Wisły Kraków S.A. zaczyna się od wskazania podstawy prawnej, analogicznej do regulaminu obiektu sportowego. W $\S 1$ ust. 2 natomiast określa zakres swojego zastosowania, twierdząc że „określa on prawa i obowiązki Organizatora, warunki udziału i zasady zachowania się uczestników imprezy masowej, w tym w szczególności postanowienia regulujące: sposób przeprowadzenia imprezy masowej, obowiązki uczestników imprezy masowej, warunki uczestnictwa w imprezie masowej, uprawnienia uczestników imprezy masowej zasady odpowiedzialności uczestników imprezy masowej za zachowanie niezgodne z regulaminem". § 2 ust. 1 jest z kolei kalką art. 5 ust. 1 ustawy o bezpieczeństwie imprez masowych, stanowiąc, iż za dbanie o „,bezpieczeństwo imprezy masowej w miejscu i czasie jej trwania odpowiada Organizator imprezy". Następnie zakłada odpłatność uczestnictwa w imprezie i reglamentacje potencjalnych adresatów. Wykładnia art. 3 ustawy

${ }^{19}$ M. Dróżdż, op. cit., s. 3-6. 
o bezpieczeństwie imprez masowych sugerowałaby komercyjny charakter imprez masowych, co nie jest jednak regułą. W wyniku wprowadzonych przez ustawodawcę modyfikacji ex lege jednak można dopatrywać się w samej ustawie różnej odpowiedzialności organizatorów w zależności od odpłatnego lub nieodpłatnego charakteru imprez masowych ${ }^{20}$. Prima facie $\S 2$ i § 3 Regulaminu imprez masowych są tożsame z § 12 i § 13 Regulaminu obiektu sportowego. Interesujący może się wydać §5 (Regulaminu imprez masowych), który zastrzega na rzecz organizatora „prawo do odmowy wyrażenia zgody na wniesienie przedmiotu, jeżeli istnieje uzasadnione podejrzenie, iż może on być użyty w celu popełnienia czynu zabronionego, określonego ustawą lub niniejszym regulaminem". Jest to bowiem wyraźny przykład potwierdzający wzmiankowane wcześniej obawy TK w kontekście art. 8 ust. 2 ustawy o bezpieczeństwie imprez masowych. Organizator oprócz obowiązków określa także uprawnienia uczestników. Na podstawie $\S 5$ są to m.in. prawo do przebywania na terenie stadionu - oczywiście od czasu udostępnienia obiektu, prawo do tego, aby w nieskrępowany sposób uczestniczyć w meczu, wyrażając swoje emocje, co jest ograniczone jedynie koniecznością przestrzegania ogólnie obowiązujących przepisów prawa oraz postanowień określonych niniejszym regulaminem, a także koniecznością poszanowania praw i godności osobistej innych uczestników imprezy masowej; do informacji o umiejscowieniu punktów medycznych, informacyjnych, gastronomicznych i sanitarnych oraz udogodnieniach, a także wymogach bezpieczeństwa określonych przez organizatora lub służby ratownicze, korzystania z urządzeń, w tym z zaplecza higieniczno-sanitarnego, które są udostępnione do ogólnego użytku, w sposób zgodny z ich przeznaczeniem, korzystania z pomocy medycznej na imprezie, korzystania z punktu depozytowego po uprzednim zgłoszeniu służbom porządkowym lub służbom informacyjnym organizatora. $\S 5$ ust. 2 przyznaje natomiast użytkownikom prawo do „niezwłocznego zgłoszenia Organizatorowi informacji i ewentualnych roszczeń na temat poniesionych przez niego szkód powstałych w trakcie i na terenie imprezy masowej, żądania od Organizatora zwrotu kosztów za niewykorzystane bilety lub karty wstępu uprawniające do udziału w imprezie masowej na zasadach określonych przez Organizatora w odrębnych regulaminach, składania skarg i wniosków". Przepisy rozdziałów VI i VII zawierają natomiast regulacje charakterystyczne

20 Ibidem. 
de facto dla wszystkich analizowanych regulaminów. Są one bowiem potwierdzeniem wyrażenia automatycznej zgody na przetwarzanie danych osobowych, wraz z chwilą „,zakupu karty kibica, biletu, karnetu, wejścia $\mathrm{w}$ posiadanie dokumentu uprawniającego do uczestnictwa $\mathrm{w}$ imprezie masowej" (§ 6 ust. 1 Regulaminu imprez masowych). Podobnie wygląda sytuacja związana ze zgodą na użycie wizerunku, która staje się obligatoryjna według regulaminu z chwilą „wejścia na teren obiektu” (§ 7 ust. 1 Regulaminu imprez masowych). Na gruncie $\S 7$ ust. 3 podtrzymano kompetencję organizatora do wydania zakazu klubowego.

Istotny głos w sprawie regulaminów obiektów i regulaminów imprez masowych zabrał członek zespołu prawa karnego biura Rzecznika Praw Obywatelskich i jednocześnie autor wniosku do Trybunału Konstytucyjnego - Marcin Warchoł ${ }^{21}$. Stwierdził on, że poprzez złożenie wniosku w istocie zaskarżono prywatyzację wymiaru sprawiedliwości, ,"czyli cedowanie uprawnień państwa w zakresie prawa represyjnego na podmioty prywatne"22. Koresponduje to z obawami wyrażanymi przez doktrynę, próbującą znaleźć odpowiedź na pytania: czy prywatyzacja w zapewnianiu bezpieczeństwa w dostatecznym stopniu jest legitymowana przez konstytucyjne zasady demokratycznego państwa prawnego i jakie są społeczne konsekwencje takich rozwiązań w zakresie prywatyzacji bezpieczeństwa? ${ }^{23}$

\footnotetext{
${ }^{21}$ Kontrola zgodności art. 54 ust. 1 stawy o bezpieczeństwie imprez masowych przez Trybunał Konstytucyjny została wszczęta na wniosek RPO - prof. Ireny Lipowicz. Ogólnopolski Związek Stowarzyszeń Kibiców zwrócił się do prof. Ireny Lipowicz, Rzecznika Praw Obywatelskich, o zbadanie regulaminu klubu WKS Zawisza Bydgoszcz. We wniosku podniesiono, iż regulamin ogranicza wolność korzystania z dóbr kultury. Dokładnie zakwestionowano zapis mówiący: „klub zastrzega sobie prawo odmowy sprzedaży biletów na mecz piłkarski dla osób i grup osób, których drużyny nie biorą udziału w zawodach".

22 www.polityka.pl/tygodnikpolityka/społeczeństwo/1582555,1,trybunal-kwestionuje-samowolke-wregulaminach-stadionowych-kibice-się-ciesza.read.
}

${ }^{23}$ Szerzej na ten temat: J. Jabłońska-Bonca, op. cit., s. 4. 


\section{ANALIZA REGULAMINÓW WYBRANYCH PŁYWALNI 24}

Przystępując do analizy przykładowych regulaminów pływalni, zauważyć należy, iż nie powołują one swojej podstawy prawnej. Przedmiot regulacji regulaminu pływalni dla wielu może wydać się wręcz oczywisty. Obydwa regulaminy, w swoich początkowych założeniach, udzielają informacji o lokalizacji pływalni oraz dniach i godzinach otwarcia. Co ważne, na samym początku określony jest również podmiot zarządzający. W przypadku pływalni w Kozienicach organem upoważnionym do wydania regulaminu jest każdorazowo dyrektor powiatowej jednostki samorządowej, czyli dyrektor Kozienickiego Centrum Rekreacji i Sportu. Statut Aquaparku Radom nie wymienia organu odpowiedzialnego za jego wydanie. Zgodnie z brzmieniem obydwu regulaminów odnosi się on także wyłącznie do użytkowników - tj. „uprawnionych do korzystania z pływalni, posiadającyh ważny bilet, karnet lub kartę stałego klienta". Interesujące może wydać się, iż podobnie jak miało to miejsce w przypadku regulaminu obiektu sportowego, regulamin pływalni również bardzo wyraźnie zakazuje jakiejkolwiek działalności komercyjnej bez uzyskania odpowiedniej zgody zarządzającego pływalnią.

Na szczególną uwagę zasługuje brak dostępu do szeroko pojętych zasobów pływalni dla niektórych podmiotów. Oba regulaminy zastrzegły to odpowiednio w $\S 2$ pkt 13 (Aquapark Radom) oraz art. 10 (pływalnia Kozienice). Nie są jednak w tych postanowieniach jednorodne i dopuszczają różny stopień szczegółowości regulacji.

Ograniczenie dotyczy osób, których stan zdrowia uniemożliwia korzystanie z zasobów pływalni. Jest to uzależnione od stanu odurzenia alkoholowego lub stanu dalece odbiegającego od ogólnych standardów higieny. Obowiązującą uprzednio regulację dotyczącą przewlekłych chorób o podłożu dermatologicznym zastąpiono zakazem wstępu dla osób z otwartymi ranami skóry oraz z przewlekłym jej zapaleniem. Takie sformułowanie jest dużo łagodniejsze i nie może być interpretowane jako potencjalnie dyskry-

\footnotetext{
24 Przedmiotem obserwacji były: Aquapark Radom mieszczący się przy ul. Chrobrego 3, jak również Kryta Pływalnia Delfin w Kozienicach przy ul. Legionów 4, znajdująca się w zarządzie Kozienickiego Centrum Rekreacji i Sportu. Regulaminy dostępne na stronach internetowych: http://www.kcris.pl/zalaczniki/2504/ REGULAMIN\%PLYWALNI\%200GOLNY. pdf oraz dotychczas pod adresem http://aquapark-radom.pl/wp content/uploads/2010/10/Regulamin_Aquaparku_w_Centrum_S\%C5\%82onecznym_wrzesien 2012. pdf - aktualnie dostęp utrudniony ze względu na zmiany na stronie internetowej pływalni.
} 
minujące. Trudno bowiem wszystkim chorobom przypisywać charakter epidemiologiczny lub zakaźny. Władze pływalni zastrzegają sobie również prawo do wydalenia z terenu zakładu osób, które dostałyby się tam bezprawnie lub będąc $\mathrm{w}$ obrębie pływalni zachowywałyby się w sposób rażąco niezgodny z normami regulaminowymi. Co ciekawe, za takie zachowaniem - zgodnie z art. 9 regulaminu Krytej Pływalni Delfin w Kozienicach - może być również uznane niedokonanie określonych czynności higieny, określonych na gruncie art. 9 jako obligatoryjnych przed wejściem na pływalnię. Aquapark Radom reguluje to w art. $11 \S 1$, nazywając swoje uprawnienie „prawem gospodarza obiektu”. Przymusowe wydalenie użytkowników w obydwu pływalniach łączy się z brakiem zwrotu pieniędzy za zakup wejściówki.

Kwestią godną uwagi jest również odpowiedzialność pływalni za ewentualne zagubienie lub kradzież rzeczy należących do użytkowników. Stosunek prawny pomiędzy zakładem a użytkownikiem rozpoczyna się z chwilą zakupu biletu. Można by zatem zakładać, iż użytkownik podlega ochronie wykonywanej chociażby przez personel pływalni. Tymczasem jedyną formą ochrony mienia zapewnioną przez pływalnię zdaje się być zapewnienie chronionych hasłem szafek znajdujących się w szatniach. W dodatku zaobserwować można różnice $\mathrm{w}$ podejściu obu pływalni w rozwiązaniu powyższej kwestii.

Regulamin Aquaparku Radom w art. $6 \S 1$ stwierdza, że „rzeczy wartościowe w szafkach i skrytkach" przechowywane są na własną odpowiedzialność. Zarząd pływalni wyłącza również swoją odpowiedzialność odpowiednio w art. 1 lub art. $2 \S 6$ zatytułowanym „odpowiedzialność cywilna”. W art. 2 zarząd stwierdza, że za „utratę, zniszczenie lub uszkodzenie przez osoby trzecie przedmiotów wniesionych na teren obiektu przez odwiedzających pływalnię" nie ponosi on odpowiedzialności. Jedyne zobowiązanie podejmowane przez pływalnię w sposób dobrowolny - explicite wymieniony w przepisach art. 1 - to utrzymanie obiektu i jego wyposażenia w stanie zapewniającym bezpieczne użytkowanie. Ogół odpowiedzialności przerzucony jest na użytkowników, bez specjalnego rozróżnienia pod kątem ponoszonej odpowiedzialności, czy ewentualnej szkody dokonali osobiście, czy szkoda została dokonana przez osoby znajdujące się pod ich wyłączną opieką (np. dzieci, uczestników zorganizowanej grupy, osoby niepełnosprawne). Ewentualne roszczenia odszkodowawcze uzależnione są pod rygorem nieważności, od niezwłocznego ich zgłoszenia (art. 4 § 6). Szczególną rolę $\mathrm{w}$ zaistniałych okolicznościach pełni monitoring. Regulamin w art. 3 § 1 stanowi, iż jest to rozwiązanie powołane w celu „zapewnienia bezpieczeń- 
stwa osób i ich mienia znajdującego się na terenie obiektu". Zgoda na monitorowanie poczytywana jest za wyrażoną od chwili zakupu biletu.

Tak formułowane regulacje są jednak niespójne. Już samo wyłączenie odpowiedzialności sugeruje sprzeczność z przepisami Kodeksu cywilnego. Co więcej, stoi to całkowitej sprzeczności z regulaminowymi postanowieniami organizatora w przedmiocie monitoringu, który służy według jego postanowień „,zapewnieniu bezpieczeństwa osób i ich mienia znajdującego się na terenie obiektu". Implikuje to mianowicie postrzeganie podmiotu zarządzającego pływalnią jako ewentualnego pośrednika potencjalnych roszczeń. Dostęp do zasobów monitoringu (prawdopodobnie obsługiwanego przez system) zależy jedynie od zgody wspominanego już podmiotu zarządzającego i poddany jest jego wyłącznej kompetencji, co również jest skutkiem prywatyzacji zadań państwowych w zakresie zapewnienia bezpieczeństwa ${ }^{25}$. Dodatkowym czynnikiem utrudniającym kontrolę nad tym procederem jest brak jednolitej regulacji ustawowej dotyczącej monitoringu.

Kwestia monitoringu ujęta jest także w regulaminie pływalni w Kozienicach. Normuje on jedynie fakt jego występowania, jak również nadmienia, iż monitoring prowadzony jest w sposób nienaruszający dóbr osobistych i godności użytkowników (art. 8). Analogicznie statut kozienickiej pływalni zakłada odpowiedzialność odszkodowawczą użytkowników „w pełnej wysokości wartości szkody" (art. 1-Odpowiedzialność). Podobnie odpowiadają również opiekunowie: dzieci, osób niepełnosprawnych, zorganizowanych grup. Organizator, tj. dyrektor Kozienickiego Centrum Rekreacji i Sportu, uchyla się również od odpowiedzialności za wszelkie szkody powstałe na skutek nieprzestrzegania regulaminu (art. 3 -Odpowiedzialność). Uwagę zwraca fakt, iż organizator nie stwierdza uchylenia się od odpowiedzialności odszkodowawczej za szkody powstałe pomimo postępowania zgodnie z regulaminem. Można zatem wywnioskować, iż możliwe jest dochodzenie roszczeń odszkodowawczych od pływalni pod warunkiem zastosowania się do wymogów określonych w art. 4 - Odpowiedzialność, a mianowicie do „umieszczenia swoich rzeczy w szafkach i ich prawidłowego zamknięcia”.

Bezpieczeństwo użytkowników rozumiane w sposób dosłowny - bezpośrednio związany z korzystaniem z pływalni - dotyczy obecności i aktywności ratowników Wodnego Ochotniczego Pogotowia Ratunkowego. Zarówno Aquapark Radom, jak i pływalnia Kozienice zobowiązują się

25 J. Jabłońska-Bonca, op. cit., s. 8. 
w regulaminie do zapewnienia bezpieczeństwa użytkownikom poprzez zapewnienie obsługi ratowników Wodnego Ochotniczego Pogotowia Ratowniczego. Jednocześnie użytkownicy zobowiązani są do bezwzględnego podporządkowania się ich instrukcjom i zaleceniom. Są to zatem podmioty odpowiedzialne za wykonywanie władztwa, którym regulamin przyznaje kompetencję do wydawania określonych nakazów i zakazów zachowania - analogicznie do sytuacji związanej z regulaminami stadionowymi. We wspominanych pływalniach nie zaobserwowano obecności pracowników ochrony. Tym samym zapewnienie porządku spoczywać będzie na pracownikach pływalni, którzy wobec niesubordynowanych użytkowników wykonywać będą swoje zwierzchnictwo do czasu przybycia Policji.

Analizowane regulaminy co do zasady są podobne, co nie znaczy jednocześnie, że identyczne. Podmioty odpowiedzialne za ich wydanie wyraźnie korzystały z ogólnej swobody kształtowania ich treści.

\section{ANALIZA REGULAMINU KLUBU NOCNEGO}

Pojęcie „selekcji” użytkowników pojawia się także w kontekście klubu nocnego. Jego kwalifikacja jest analogiczna do pływalni. Jest to zatem w czystej formie akt regulujący określony porządek wewnętrzny.

Początkowe postanowienia informuja, iż warszawski klub DeLitte jest spółką i określają jego dokładną lokalizację ,wskazując również podmiot prowadzący. W pkt 2 organ zarządzający enumeratywnie określa katalog podmiotów uprawnionych do wejścia na teren klubu. Oprócz osób posiadających bilet mogą to być również przedstawiciele „prasy, radia i innych mediów posiadających ważną akredytację na daną imprezę" lub przedstawiciele służb państwowych, o ile uprawnieni są oni do przeprowadzenia czynności kontrolnych. Warunkiem ich obecności jest jednak ważność legitymacji służbowych oraz uzgodnienie ich obecności z przedstawicielem klubu. W związku z nakreślonym powyżej stanem faktycznym, tym bardziej interesujący wydaje się pkt 4. Stanowi on, że "osoby uczestniczące $w$ imprezach organizowanych przez klub mają formalny obowiązek zapoznania się z regulaminem". Jest to warunek, który nie może zostać spełniony z przyczyn obiektywnie niezależnych od woli klientów. Regulamin bowiem nie został - zgodnie z powszechnie obowiązującymi standardami 
- wywieszony w widocznym miejscu. Jak podano wynikało to z niedopracowania jego szaty graficznej do estetyki miejsca. Sugeruje to swoistą niekonsekwencję organu kierującego, który utrzymując taką regulację, przeczy swoim postanowieniom. Ponadto regulamin w dalszej części kontrowersyjnego pkt 4 stanowi, że „wejście do klubu jest jednoznaczne z jego [regulaminu - przyp. red.] akceptacją".

Kolejne normy stanowia, iż klient nie może wnosić na teren klubu broni lub innych niebezpiecznych przedmiotów. Jest to o tyle oczywiste, o ile założymy, że mógł on zapoznać się z tymi założeniami przed wejściem do klubu. W związku z powyższym klub zastrzega sobie prawo do przeszukania klientów, wobec których istnieje podejrzenie wniesienia lub co najmniej posiadania przedmiotów z pkt 7 (takich, które mogą stanowić potencjalne zagrożenie). W przypadku wykrycia takowych, zostają one odebrane oraz oddane odpowiednim służbom. W regulaminie uregulowana jest także idealna, z punktu widzenia organu zarządzającego, procedura doboru klientów. Stąd „do lokalu nie będą wpuszczone osoby nietrzeźwe, pod wpływem środków odurzających, agresywne, posiadające przedmioty z pkt 7, (...) niepoddające się kontroli wspomnianej w pkt 8 oraz osoby z orzeczonym zakazem wstępu do klubu" (pkt 11). Naturalnie, zgodnie z postanowieniami pkt 12 do klubu wstęp mają jedynie osoby pełnoletnie, których tożsamość może zostać poddana uprzedniej weryfikacji przez pracownika ochrony. Działania powyższe prowadzą do selektywnego doboru klientów. Sam klub wspomina o tym w pkt 16 swojego regulaminu. Z jego treści explicite wynika opis tzw. selekcji przy bramkach. Zgodnie z jego brzmieniem „o możliwości wejścia do Klubu decyduje selekcjoner”. Regulamin natomiast nie stanowi jednak, iż nie musi on podawać powodu, dla którego osoba nie została wpuszczona do lokalu (art. 17). Jeśli ktoś domagałby się uzasadnienia, to pośrednio dostarcza go art. 18 regulaminu, który brzmi: „W przypadku braku miejsca w Klubie, Selekcjoner wedle własnego uznania zawsze ma prawo odmówić wpuszczenia gości".

Do kwestii selekcji klientów (użytkowników) odniósł się pośrednio także Sąd Okręgowy w Łodzi w wyroku z dnia 16 lutego 2015 r. ${ }^{26}$ Sąd wyraźnie

26 Wyrok Sądu Okręgowego w Łodzi z dnia 16 lutego 2015 r., II C 1551/14. We wzmiankowanej sprawie Sąd rozpatrywał roszczenie odszkodowawcze powoda wobec właściciela klubu - restauracji, w której został on zaatakowany przez nieustalonych sprawców, w wyniku czego doznał uszczerbku na zdrowiu. Powód domagał się od właściciela lokalu odszkodowania, twierdząc, iż podlegał on obowiązkowej ochronie gwarantowanej przez pracowników lokalu przez sam fakt przebywania na jego obszarze. Podnosił 
stwierdził, iż samo przebywanie na terenie klubu jako klient (użytkownik) nie przesądza o istnieniu stosunku zobowiązaniowego pomiędzy klientem a zarządcą lokalu. Jednym z jego przejawów miało być zagwarantowanie dostatecznej ochrony poszkodowanemu klientowi. W efekcie Sąd Okręgowy nie stwierdził istnienia jakichkolwiek norm prawnych, które przesądzałyby, iż pracownicy ochrony obecni w lokalu zobowiązani są zapewnić ochronę osobistą lub mienia klientów lokalu. Sąd Okręgowy nie doszukał się istnienia szczególnych wymogów związanych z zapewnieniem ochrony ani $w$ ustawie o bezpieczeństwie imprez masowych, ani w ustawie $z$ dnia 22 sierpnia 1997 r. o ochronie osób i mienia ${ }^{27}$. Nie wywiódł istnienia takich norm również z ustawy z dnia 26 października 1982 r. o wychowaniu w trzeźwości i przeciwdziałaniu alkoholizmowi (tekst jedn. Dz.U. z 2012 r., poz. 1356). W podobny sposób odniósł się do ewentualnej odpowiedzialności deliktowej właściciela lokalu. Tymczasem istnienie złożonego (składającego się z 32 kamer) systemu monitoringu oraz przeprowadzanie wnikliwej selekcji zostało potraktowane przez Sąd Okręgowy jako ostatecznie wyłączające odpowiedzialność deliktową. Uznano bowiem, iż takie rozwiązania czynią zadość wymogowi szczególnej staranności, który to spoczywa na podmiocie wykonującym określoną działalność zawodową.

Spółka zarządzająca klubem, w zakresie selekcji i relacji z klientami, nie podlega kontroli innej niż ustanowiona przez siebie samą. Zgodnie z brzmieniem art. 21 pracownicy ochrony „mają prawo wymusić opuszczenie Klubu przez osoby zachowujące się w sposób zagrażający życiu lub zdrowiu gości lub pracowników". Takie zachowanie wymaga jednak od ochrony szczególnej staranności i musi odbyć się, „,nie powodując nadmiernych dolegliwości" po stronie wyproszonych gości, z zastrzeżeniem ochrony koniecznej. Każda szkoda wyrządzona na terenie Klubu wiąże się z odpowiedzialnością karną oraz materialną (art. 24).

Instytucja Policji pojawia się w regulaminie tylko raz. Zgodnie z brzmieniem art. 22 - osoby wyrządzające szkody materialne, popełniające wykroczenia lub zachowujące się niestosownie mogą zostać ujęte przez ochronę $\mathrm{i}$ „niezwłocznie przekazane Policji”. To właśnie pracownicy ochrony (w tym przypadku klubu nocnego), a nawet ratownicy Wodnego Ochotniczego Pogotowia Ratunkowego (w przypadku pływalni) są odpowiedzialni za zapro-

jednocześnie, iż uszczerbek, którego doznał wynika z niewłaściwego wykonania zobowiązania przez pracowników ochrony. Sąd Okręgowy nie przyznał jednak słuszności tak przyjętemu rozumowaniu.

27 Ustawa z dnia 22 sierpnia 1997 r. o ochronie osób i mienia (Dz.U. z 1997 r. Nr 114, poz. 740 ze zm.). 
wadzenie porządku i ochronę osób i mienia zgodnie z zasadami wskazanymi przez ustawę o ochronie osób i mienia. Żaden regulamin nie zawiera jednak szczegółowych informacji dotyczących sposobu działania uprawnionych, zakresu przysługujących im uprawnień ani ewentualnych konsekwencji podejmowanych przez nich działań. Osoba objęta zakresem obowiązywania regulaminu poddana będzie czynnościom w nim wskazanym (np. przymusowemu opuszczeniu lokalu nawet z użyciem środków przymusu), niemniej sposób ich przeprowadzenia uregulowany będzie w zupełnie innym akcie prawnym. Poddany czynnościom służbowym wykonywanym przez pracowników ochrony będzie podlegał przepisom art. 36 ust. 5 ustawy z dnia 22 sierpnia 1997 r. o ochronie osób i mienia uszczegółowionych przez $\S 8$ rozporządzenia $z$ dnia 19 grudnia $2013 \mathrm{r}$. w sprawie szczegółowego trybu działania pracowników ochrony ${ }^{28}$. Zgodnie z treścią norm powyższych aktów prawnych, czynności pracowników ochrony klubu nocnego powinny sprowadzać się, w odniesieniu do klienta stwarzającego zagrożenie, w szczególności do niezwłocznego powiadomienia Policji i oddania zatrzymanego w jej ręce.

Zgodnie z ogólnie przyjętą w kwestii regulaminów praktyka, klub uwalnia się od odpowiedzialności za rzeczy pozostawione przez gości np. w szatni. W żadnym z punktów regulaminu nie ma jednak regulacji dotyczącej monitoringu, chociaż powszechnie wiadomo, iż występuje on i znajduje zastosowanie. Za jego obsługę nie jest jednak odpowiedzialny nikt z ochrony. Jest on wewnętrzną, a zarazem wyłączną kwestią organizatora. W związku z powyższym dostęp do jego zapisów mają wyłącznie pracownicy klubu. Jak udało się ustalić, jest to system w pełni skomputeryzowany, który gromadzi dane z ostatnich 28 dni. Po upływie tego czasu dane podlegają automatycznemu usunięciu.

Na wyróżnienie zasługuje, zwłaszcza w zakresie prawa ochrony danych osobowych, artykuł 30. Na jego podstawie każdy z obecnych wyraża zgodę na „nieodpłatne rozpowszechnianie ich wizerunku”. Zastrzeżenie to dotyczy zwłaszcza, ale niestety nie wyłącznie, zdjęć publikowanych na stronie klubu. W ramach pewnej etykiety fotografowie pytają jednak $\mathrm{z}$ pewnym wyprzedzeniem, czy mogą wykonać zdjęcie. Według art. 32 „Regulamin obowiązuje od 22.03.2012 roku”. Na uwagę zasługuje fakt, że obowiązywanie

28 Rozporządzenie Rady Ministrów z dnia 19 grudnia 2013 r. w sprawie szczegółowego trybu działań pracowników ochrony (Dz.U. z 2013 r., poz. 1681 ze zm.). 
regulaminu nie wpłynęło na jego odpowiednie ogłoszenie. Chociaż regulamin klubu nie uzależniał swojego obowiązywania od jego ogłoszenia, to co najmniej pożądane, z punktu widzenia klientów, byłoby jego ogłoszenie, nawet jeśli podkreślimy, iż nie miał on charakteru prawnego.

\section{BIBLIOGR AF I A}

Dróżdż M., Definicja imprezy masowej - teoria a praktyka, „Edukacja Prawnicza” 2013, nr 10.

Jabłońska-Bonca J., Policentryczność źródeł norm w zakresie bezpieczeństwa obywateli. Problem czy margines?, „Krytyka Prawa” 2015, nr 1.

Kąkol C., Komentarz do art. 54 Ustawy o bezpieczeństwie imprez masowych, LEX 2012.

Kurzępa B., Przestępstwa i wykroczenia z ustawy o bezpieczeństwie imprez masowych, „Prokuratora i Prawo” 2009, nr 10. 